\title{
FAKTOR-FAKTOR YANG MEMPENGARUHI PRODUKSI, KONSUMSI, DAN HARGA BERAS DI PROVINSI ACEH
}

\author{
(Factors Affecting Production, Consumption, and Price of Rice In Aceh \\ Province)
}

\author{
Ade Israwati, Zakiah ${ }^{1}$, T. Makmur ${ }^{\mathbf{1}^{*}}$ \\ ${ }^{1}$ Program Studi Agribisnis, Fakultas Pertanian, Universitas Syiah Kuala
}

\begin{abstract}
Abstrak. Beras yang menjadi bagian bulir tanaman padi (Oryza Sativa L.) merupakan salah satu penganan pokok (primer) di Indonesia. Beras menjadi komoditas penting di Indonesia karena negara ini memiliki konsumsi beras per kapita terbesar di dunia. Provinsi Aceh merupakan salah satu provinsi dengan produksi padi tertinggi dan cukup stabil di Indonesia. Tujuan penelitian ini adalah untuk mengetahui faktor-faktor apa saja yang mempengaruhi produksi, konsumsi, dan harga beras di Provinsi Aceh dengan menggunakan metode penelitian kuantitatif. Metode yang digunakan dalam penelitian adalah metode kualitatif (deskriptif) dan metode kuantitatif. Model yang digunakan adalah modifikasi model ekonometri, yaitu metode 2SLS (two stage least square). Hasil penelitian menunjukkan bahwa produksi beras di Provinsi Aceh dipengaruhi oleh harga beras lokal, harga gabah tingkat petani, luas areal panen dan harga pupuk. Konsumsi beras di Provinsi Aceh dipengaruhi oleh harga beras lokal dan pendapatan perkapita penduduk. Dan harga jual beras lokal Provinsi Aceh produksi beras dan konsumsi beras.
\end{abstract}

\section{Kata kunci: Pangan, Beras, Produksi, Konsumsi, Harga}

\begin{abstract}
Rice that come from rice plant (Oryza Sativa L.), is one of staple food (primary) in Indonesia. Rice become important commodity in Indonesia because this country being the largest rice consumption per capita in the world. Aceh province is one of province with the highest rice production and stable enough in Indonesia. This study aims to determine what factors that affect production, consumption, and price in Aceh, which is this sudy uses quantitative research method. The method that used in this research is qualitative method (descriptive) and quantitative method. The model that used is modification of econometric model, which is 2SLS method (two stage least square). The result of this study showed that rice production in Aceh Province are affected by local rice prices, grain prices on farmers level, harvest area, and fertilizer prices. Rice consumption in Aceh Province are affected by local rice prices and income per capita. And local rice prices in Aceh Province are affected by rice production and rice consumption.
\end{abstract}

\section{Keywords: Food, Rice, Production, Consumption, Price}

\section{PENDAHULUAN}

Pangan merupakan salah satu kebutuhan pokok (primer) yang dibutuhkan oleh manusia. Pangan menjadi kebutuhan paling utama diantara kebutuhan pokok sandang dan papan. Pangan merupakan kebutuhan dasar yang permintaannya terus meningkat seiring dengan perkembangan ju Bagi masyarakat Indonesia, yang menjadi pangan utama adalah beras. Menurut Ariani (1998), ada empat alasan dipilihnya beras sebagai bahan pangan karbohidrat paling utama (pokok).

Keempat alasan tersebut adalah: (1) beras mempunyai rasa lebih enak; (2) mempunyai nilai sosial yang lebih tinggi; (3) jika dibandingkan pangan karbohidrat 
lainnya, pengolahan beras lebih cepat dan lebih praktis, dan; (4) beras mempunyai komposisi nilai gizi relatif tinggi.

Indonesia sebagai negara dengan jumlah konsumsi beras terbesar, dirasa harus mampu memenuhi kecukupan pangan dalam negeri. Menurut Amang (1995), suplai dari dalam negeri harus dipandang sebagai andalan utama dan suplai dari luar negeri hanyalah sebagai tambahan apabila suplai dalam negeri berkurang.

Provinsi Aceh sendiri memiliki potensi besar di bidang pertanian dan sub sektor pertanian yang ada. Daerah Aceh mampu menghasilkan beras, ubi kayu, ubi jalar, jagung, sayur-sayuran, dan buah-buahan, hingga tanaman perkebunan.

Dibalik cukup besarnya angka surplus beras dalam dua puluh tahun ini, Pemerintah mengaku masih melakukan impor beras. Alasan pemerintah lebih tertarik memilih impor beras salah satunya adalah harga beli pemerintah terhadap beras impor lebih murah dibandingkan harga beli pemerintah terhadap petani lokal. Dengan harga yang lebih murah tersebut Perum Bulog mengaku pemerintah sudah bisa mendapatkan kualitas beras di tingkat medium. Kebutuhan beras di Perum Bulog sendiri digunakan sebagai kebutuhan pemenuhan permintaan pasar, kebutuhan subsidi beras miskin (raskin), hingga kebutuhan siaga bencana. Hal ini sering menjadi dilema dalam masalah pangan beras. Dibalik keinginan dan usaha pemerintah untuk menyelamatkan petani, pemerintah Aceh masih harus menerima beras hasil produksi luar negeri.

Ada beberapa kendala yang masih menjadi kendala menjaga kestabilan ketersediaan beras yang dihadapi oleh pemerintah yaitu tingkat produksi beras, konsumsi beras dan harga beras. Pada tingkat produksi beras selain ketergantungan pada kondisi iklim, kegiatan usahatani padi sawah di Provinsi Aceh juga dipengaruhi faktor eksternal seperti kondisi harga beras lokal, harga gabah pada tingkat petani, luas areal tanam dan harga pupuk. Dimana harga beras lokal akan mempengaruhi minat para petani untuk meningkatkan produksi beras, sehingga apabila harga gabah ditingkat petani dirasakan memberikan pendapatan yang layak kepada para petani, maka sebagian besar petani akan mencoba bercocok tanam di sektor pertanian tanaman pangan ini. Selain itu penambahan luas areal tanam juga akan mempengaruhi produksi padi sawah itu sendiri selain masalah harga pupuk yang dimana pupuk merupakan kebutuhan utama dalam usahatani padi sawah.

Kemudian masalah utama yang ditemukan yakni pada proses penanganan pasca panen padi, dimana menurut Perum Bulog petani Aceh sangat perlu dibantu dalam teknologi pasca panen. Hal ini diperlukan guna mendorong peningkatan kualitas beras dan ekonomi masyarakat Aceh itu sendiri. Karena selama ini petani Aceh masih menggunakan cara manual dalam proses pengolahan pasca panen padi mereka. Sehingga tidak heran jika ditemukan banyak beras yang menyusut dan kualitas yang dihasilkan kurang bagus. Bahkan sebagian petani lebih memilih menjual hasil padi mereka dalam bentuk gabah keluar daerah, seperti daerah Sumatera Utara.

Faktor harga beras lokal juga mempengaruhi konsumsi beras dimana harga yang mengalami kenaikan akan mempengaruhi daya beli terhadap beras sehingga orang yang tidak mampu akan mengurangi konsumsi beras tersebut. Selain itu pendapatan perkapita masyarkat yang jauh dari cukup dapat mempengaruhi tingkat konsumsi beras. 
Dalam proses konsumsi, kendala yang dihadapi akibat peningkatan jumlah penduduk adalah kebutuhan akan pangan pokok beras yang semakin meningkat pula. Kebutuhan akan pangan pokok beras tentu harus diimbangi oleh ketersediaan beras yang cukup tiap tahunnya serta harga beras yang stabil. Pemerintah, dalam hal ini Bulog, selalu berupaya mengamankan stok beras bagi Provinsi Aceh. Namun hal tersebut tidak bisa menjamin usaha pembangunan pertanian dalam hal swasembada pangan beras, mengingat Provinsi Aceh masih bergantung pada daerah lain.

Pada permasalahan harga beras lokal, sangat dipengaruhi oleh kondisi jumlah produksi beras, artinya bila beras yang diproduksi sedikit akan tetapi permintaan tinggi, maka akan meningkatkan harga. Hal ini sesuai dengan hukum permintaan, selain itu pada konsumsi beras juga dapat dilihat bahwa bila permintaan mengalami kenaikan, maka terjadi pengurangan stok produksi dan pada akhirnya akan mengakibatkan kenaikan harga beras lokal.

\section{METODE PENELITIAN}

\section{Lokasi, Objek, dan Ruang Lingkup Penelitian}

Lokasi penelitian dilakukan di Provinsi Aceh dengan objek penelitian faktor-faktor yang mempengaruhi produksi, konsumsi, dan harga beras di Provinsi Aceh. Ruang lingkup penelitian terbatas pada permasalahan faktor-faktor yang mempengaruhi produksi, konsumsi dan harga beras.

\section{Metode Pengambilan Sampel}

Metode yang digunakan dalam penelitian ini adalah metode penelitian kuantitatif dengan menggunakan jenis data sekunder rentang waktu (time series) dari tahun 1993 sampai dengan tahun 2015.

\section{Metode Analisis Data}

Metode yang digunakan dalam penelitian adalah metode kualitatif (deskriptif) dan metode kuantitatif. Metode kuantitatif untuk menganalisis faktorfaktor yang mempengaruhi produksi dan konsumsi beras di Provinsi Aceh adalah dengan model persamaan simultan. Sedangkan analisis kualitatif (deskriptif) dalam penelitian ini digunakan untuk memberikan penjelasan terhadap perkembangan produksi dan konsumsi beras di Provinsi Aceh.

\section{HASIL PENELITIAN DAN PEMBAHASAN \\ 1. Analisis Faktor-faktor yang mempengaruhi Produksi, Konsumsi, dan Beras di Provinsi Aceh}

\subsection{Produksi}

Produksi beras di Provinsi Aceh dipengaruhi oleh Harga Beras Lokal, harga beras bulog, Harga beras impor, Harga Jagung lokal, harga gabah pada tingkat penggilingan, harga gabah pada tingkat petani dan Luas areal tanam padi. Hasil estimasi parameter produksi beras di Provinsi Aceh dapat dilihat pada tabel berikut ini. 
Tabel 1. Hasil Analisis Faktor-faktor Yang Mempengaruhi Produksi Beras di Provinsi Aceh dari Tahun 1993 - 2015

\begin{tabular}{lrr}
\hline \multicolumn{1}{c}{ Variabel } & Coeefisien Regresi & \multicolumn{1}{c}{$\mathbf{t}_{\text {cari }}$} \\
\hline Harga Beras Lokal & -55.826 & -3.479 \\
Harga Gabah Tk. Petani (HGPET) & -18.810 & -0.3862 \\
Luas Areal Panen (LAP) & 3.2563 & 8.316 \\
Harga Pupuk (HPK) & -0.83528 & -6.932 \\
Constant & -25684000000 & \\
\hline $\mathbf{R}^{\mathbf{2}} \mathbf{= 0 , 8 2 1 2}$ & $\mathbf{t}_{\text {tabel }}=\mathbf{2 . 0 7 3}$ \\
& $\mathbf{F}_{\text {tabel }}=\mathbf{5 , 6 9}$ \\
\hline
\end{tabular}

Adapun persamaan regresi linier sebagai berikut :

\section{PB $=-25684000000$ - 55,826 HBL -18,810 HGPET + 3,2563 LAP - 0,083528 HPPK + $\mathbf{e}_{1}$}

Berdasarkan persamaan regresi diatas, maka di dapat arti sebagai berikut :

- Apabila dilihat dari hasil regresi maka besarnya nilai kostanta 25.684.000.000 mempunyai arti bila persamaan diatas tidak memiliki harga beras lokal, harga gabah pada tingkat petani, luas areal tanam padi, dan harga pupuk maka jumlah produksi turun sebesar 25.684.000.000 Kg per tahun.

- Pada setiap penambahan harga jual beras lokal sebesar 1 Rupiah, maka akan menurunkan jumlah produksi sebesar 55,826 ton. Dengan asumsi faktor-faktor lain dalam keadaan tetap. Secara parsial diperoleh $t_{\text {cari }}=3,479>t_{\text {tabel }}=2,073$. Kondisi ini sesuai dengan hipotesis, maka terima Ha tolak Ho. Hal ini adanya upaya untuk meningkatkan harga jual beras di tingkat pedagang dengan cara mengurangi jumlah produksi beras di tingkat pedagang sehingga harga jual beras di tingkat konsumen akan mengalami kenaikan secara sistematis.

- Pada setiap penambahan harga gabah pada tingkat petani sebesar 1 Rupiah, maka akan meningkatkan jumlah produksi sebesar 18,810 Ton. Dengan asumsi faktor-faktor lain dalam keadaan tetap. Secara parsial diperoleh $\mathrm{t}_{\text {cari }}=0,3862<$ $\mathrm{t}_{\text {tabel }}=2,073$. Kondisi ini sesuai dengan hipotesis, maka terima Ho tolak Ha. Peningkatan harga jual gabah pada tingkat petani, lebih kepada merangsang petani dalam meningkatkan pendapatan usahatani, tidak akan mempengaruhi produksi beras itu sendiri, dengan demikian harga jual gabah pada tingkat petani tidak berpengaruh terhadap produksi beras.

- Pada setiap penambahan luas areal panen sebesar 1 Ha, maka akan meningkatkan jumlah produksi sebesar 3.2563 ton. Dengan asumsi faktor-faktor lain dalam keadaan tetap. Secara parsial diperoleh $t_{\text {cari }}=8,316>t_{\text {tabel }}=2,073$. Kondisi ini sesuai dengan hipotesis, maka terima Ha tolak Ho. Hal ini disebabkan dengan adanya peningkatan luas areal panen padi tentunya akan mempengaruh jumlah produksi beras.

- Pada setiap penambahan harga pupuk sebesar 1 Rupiah, maka akan menurunkan jumlah produksi sebesar 0,083528 ton. Dengan asumsi faktor-faktor lain dalam keadaan tetap. Secara parsial diperoleh $t_{\text {cari }}=6,932>t_{\text {tabel }}=2,073$. Kondisi ini sesuai dengan hipotesis, maka terima Ha tolak Ho. Hal ini disebabkan pupuk merupakan salah satu faktor produksi padi, dimana kenaikan harga pupuk akan mempengaruhi biaya produksi padi bila harga pupuk terlalu tinggi, 
menyebabkan para petani tidak mampu membeli pupuk yang berkualitas sehingga produktivitas padi juga menurun akibat tidak diberi pupuk, sehingga pada akhirnya produksi gabah menurun dan juga produksi beras menurun. Hasil ini sesuai dengan kriteria ekonomi bahwa jika harga input produksi meningkat maka penggunaan terhadap faktor produksi akan berkurang. Faktor produksi yang digunakan dalam penelitian ini adalah pupuk urea yang merupakan pupuk utama yang umum digunakan oleh petani. Kenyataannya, apabila terjadi kenaikan harga pupuk urea, maka petani akan mengurangi jumlah pembelian pupuk urea yang akhirnya juga akan berkurangnya jumlah penggunaan pupuk urea, sehingga produksi padi berkurang dan luas areal panen juga berkurang. Begitu pula sebaliknya jika terjadi penurunan harga pupuk urea. Jika harga pupuk urea murah, maka petani akan mudah mendapatkan pupuk, sehingga petani menambah jumlah penggunaan pupuk dan akan meningkatkan lahan garapannya yang pada akhirnya dapat meningkatkan luas areal panen padi.

- Untuk mengetahui besarnya pengaruh harga beras lokal, harga gabah pada tingkat petani, luas areal tanam padi, dan harga pupuk terhadap jumlah produksi beras sebesar $82,12 \%$ sedangkan sisanya sebesar $17,88 \%$ dijelaskan oleh faktorfaktor lain diluar persamaan.

\subsection{Konsumsi}

Konsumsi beras di Provinsi Aceh dipengaruhi oleh harga beras lokal (HBL) dan pendapatan perkapita (PP). Hasil estimasi parameter konsumsi beras di Provinsi Aceh dapat dilihat pada tabel berikut:

Tabel 2. Hasil Analisis Pada Faktor-faktor Yang Mempengaruhi Konsumsi Beras di Provinsi Aceh dari Tahun 1993 - 2015

\begin{tabular}{lrr}
\hline \multicolumn{1}{c}{ Variabel } & Coeefisien Regresi & \multicolumn{1}{c}{$\mathbf{t}_{\text {cari }}$} \\
\hline Harga Beras Lokal (HBL) & -3.5038 & -3.658 \\
Pendapatan Perkapita (PP) & 0.013312 & 4.030 \\
Constant & 332800 & \\
\hline $\mathbf{R}^{\mathbf{2}} \mathbf{= 0 , 8 0 0 5}$ & & $\mathbf{t}_{\text {tabel }}=\mathbf{2 . 0 7 3}$ \\
\hline
\end{tabular}

Adapun persamaan regresi linier sebagai berikut :

$\mathrm{KB}=322.800-3.50 \mathrm{HBL}+0.013312 \mathrm{PP}+\mathrm{e}_{2}$

Berdasarkan persamaan regresi diatas, maka di dapat arti sebagai berikut:

- Apabila dilihat dari hasil regresi maka besarnya nilai costanta 322.800 mempunyai arti bila persamaan diatas tidak memiliki harga beras lokal dan pendapatan perkapita maka konsumsi beras naik sebesar 322.800 ton per tahun.

- Pada setiap penambahan harga beras lokal sebesar 1 Rupiah, maka akan menurunkan jumlah konsumsi beras sebesar 3,5038 ton. Dengan asumsi faktorfaktor lain dalam keadaan tetap. Secara parsial diperoleh $t_{\text {cari }}=3,658>t_{\text {tabel }}=$ 2,073. Kondisi ini sesuai dengan hipotesis, maka terima Ha tolak Ho. Hal ini disebabkan peningkatan harga beras lokal yang cukup tinggi tentunya akan mempengaruhi para konsumen untuk mengkonsumsi beras dalam kondisi normal, dengan demikian para konsumen akan melakukan penghematan biaya rutin rumah tangga dengan cara mengurangi konsumsi beras dan mencari makanan alternatif atau subtitusi. Hal ini sesuai dengan konsep cateris paribus. 
Akan tetapi pengaruhnya tidak nyata secara statistik. Artinya dapat dilihat kondisi di lapangan bahwa berapa pun harga beras masyarakt Aceh tetap mengkonsumsi beras, karena beras merupakan bahan pangan pokok, maka penduduk akan berusaha untuk memenuhinya.

- Pada setiap penambahan pendapatan perkapita sebesar 1 Rupiah, maka akan menurunkan jumlah konsumsi beras sebesar 0,013312 ton. Dengan asumsi faktor-faktor lain dalam keadaan tetap. Secara parsial diperoleh $t_{\text {cari }}=4,030>$ $\mathrm{t}_{\text {tabel }}=2,073$. Kondisi ini sesuai dengan hipotesis, maka terima Ha tolak Ho. Peningkatan pendapatan perkapita akan mempengaruhi daya beli konsumen terhadap beras, dengan pendapatan perkapita yang lebih baik tentunya konsumen akan mampu membeli beras sesuai dengan kebutuhan, oleh karena itu pendapatan perkapita berpengaruh positif terhadap konsumsi beras. Hal ini sesuai dengan konsep cateris paribus. Akan tetapi pengaruh tersebut tidak signifikan secara statistik maka dapat diambil kesimpulan bahwa beras merupakan bahan pangan pokok bagi penduduk Aceh pada umumnya, sehingga pengaruh pendapatan seseorang tidak berpengaruh nyata terhadap konsumsi beras yang merupakan bahan pangan pokok, bahkan cenderung tetap.

- Untuk melihat variabel bebas terhadap variabel terikat digunakan koefesien determinasi $\left(\mathrm{R}^{2}\right)$ sebesar 0,8005 , artinya variabel harga beras lokal, dan pendapatan perkapita terhadap jumlah produksi beras sebesar 80,05\% sedangkan sisanya sebesar $19,95 \%$ dijelaskan oleh faktor-faktor lain diluar persamaan.

\subsection{Harga Beras Lokal}

Harga beras di Provinsi Aceh dipengaruhi oleh produksi beras (PB) dan konsumsi beras (KB). Hasil estimasi parameter harga beras lokal di Provinsi Aceh dapat dilihat pada tabel berikut ini:

Tabel 3. Hasil Analisis Pada Faktor-faktor Yang Mempengaruhi Harga Beras Lokal di Provinsi Aceh dari Tahun 1993 - 2015

\begin{tabular}{lrr}
\hline \multicolumn{1}{c}{ Variabel } & Coeefisien Regresi & \multicolumn{1}{c}{$\mathbf{t}_{\text {cari }}$} \\
\hline Produksi Beras (PB) & -0.012134 & -2.696 \\
Konsumsi Beras (KB) & 0.033709 & 3.207 \\
Constant & 742.63 & \\
\hline $\mathbf{R}^{\mathbf{2}} \mathbf{\mathbf { 0 , 6 5 9 9 }}$ & & $\mathbf{t}_{\text {tabel }}=\mathbf{2 . 0 7 3}$ \\
\hline
\end{tabular}

Adapun persamaan regresi linier sebagai berikut :

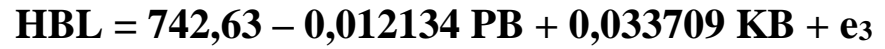

Berdasarkan persamaan regresi diatas, maka di dapat arti sebagai berikut :

- Apabilan dilihat dari hasil regresi maka besarnya nilai konstanta 742,63 mempunyai arti bila persamaan diatas tidak memiliki variabel produksi beras dan konsumsi beras, maka harga beras lokal turun sebesar 742,63 rupiah per tahun.

- Pada setiap penambahan jumlah produksi sebesar 1 ton, maka akan menurunkan harga beras lokal sebesar 0,012134 Rupiah. Dengan asumsi faktor-faktor lain dalam keadaan tetap. Secara parsial diperoleh $t_{c a r i}=2,696>t_{\text {tabel }}=2,073$. Kondisi 
ini sesuai dengan hipotesis, maka terima Ha tolak Ho. Hal ini disebabkan peningkatan jumlah produksi beras akan mempengaruhi harga beras, hal ini sesuai dengan teori Law of diminishing returns, dimana semakin banyaknya barang, maka harga semakin rendah; dan sebaliknya semakin sedikitnya barang, maka harga semakin tinggi. Dengan demikian jumlah produksi beras berpengaruh positif terhadap harga jual beras lokal. Hasil analisis ini sesuai dengan kondisi di lapangan bahwa jika terjadi panen raya, produksi beras meningkat dapat menurunkan harga eceran beras dan jika pada saat musim paceklik, harga beras meningkat karena produksi beras atau ketersedian beras menurun.

- Pada setiap penambahan konsumsi beras sebesar 1 ton, maka akan meningkatkan harga beras lokal sebesar 0,033709 Rupiah. Dengan asumsi faktor-faktor lain dalam keadaan tetap. Secara parsial diperoleh $t_{\text {cari }}=3,207>$ $\mathrm{t}_{\text {tabel }}=2,073$. Kondisi ini sesuai dengan hipotesis, maka terima Ha tolak Ho. Kondisi ini disebabkan peningkatan konsumsi menyebabkan stok beras semakin menipis, sehingga para pedagang menaikan harga beras, kondisi ini sesuai dengan teori Law of diminishing returns, dimana semakin banyaknya barang, maka harga semakin rendah; dan sebaliknya semakin sedikitnya barang, maka harga semakin tinggi. Hal ini menyebabkan jumlah konsumsi berpengaruh positif terhadap harga jual beras lokal. Selain itu dapat juga dilihat dari segi cateris paribus. Dengan tingkat konsumsi beras yang tinggi, mengakibatkan harga beras semakin tinggi.

- Untuk mengetahui besarnya pengaruh produksi beras dan konsumsi beras, terhadap harga beras lokal dilihat dari hasil uji koefesien determinasi $\left(\mathrm{R}^{2}\right)$ sebesar 0,6599, artinya variabel produksi beras dan konsumsi beras terhadap harga beras lokal sebesar 65,99\% sedangkan sisanya sebesar $34,10 \%$ dijelaskan pada variabel diluar penelitian.

\section{KESIMPULAN DAN SARAN}

Hasil analisis 2 SLS terhadap persamaan produksi beras di Provinsi Aceh dipengaruhi oleh harga beras lokal, harga gabah tingkat petani, luas areal panen dan harga pupuk. Dimana hanya variabel harga beras lokal, luas areal panen, dan harga beras lokal yang berpengaruh nyata. Sedangkan variabel harga gabah tingkat petani tidak berpengaruh nyata terhadap produksi beras. Untuk persamaan konsumsi beras di Provinsi Aceh, dipengaruhi oleh harga beras lokal dan pendapatan perkapita. Kedua variabel berpengaruh nyata terhadap tingkat konsumsi beras. Sedangkan untuk persamaan harga jual beras lokal di Provinsi Aceh dipengaruhi oleh produksi beras dan konsumsi beras. Kedua variabel berpengaruh nyata terhadap tingkat harga jual beras.

Dalam menjaga produksi beras di Provinsi Aceh diharapkan kepada pemerintah tetap terus memperhatikan ketersedian faktor produksi yang baik, memadai, dan dengan harga yang terjangkau bagi petani. Serta pemerintah perlu memberikan perhatian lebih terhadap tingkat konversi lahan yang terus meningkat setiap tahun nya. Dan bagi masyarakat Aceh sekiranya dapat mencoba mengurangi ketergantungan akan beras sebagai bahan konsumsi sehari-hari, dengan mengganti konsumsi beras kepada bahan pangan lain seperti umbi-umbian atau buah-buahan. 


\section{DAFTAR PUSTAKA}

Amang, B. 1995. Sistem Pangan Nasional. PT. Dharma Karsa Utama. Jakarta.

Ariani, M., dkk. 1998. Arah Diversifikasi Konsumsi Pangan: Kajian Tingkat Partisipasi dan Konsumsi Beras, serta Pangan Sumber Karbohidrat Lainnya. Dalam Prosiding Dinamika Ekonomi Pedesaan dan Peningkatan Daya saing Sektor Pertanian, Buku I. Pusat Penelitian Sosial Ekonomi Pertanian, Bogor.

Arifin, Imamul, Giana Hadi W. 2009. Membuka Cakrawala Ekonomi. PT Setia Purna Inves, Jakarta.

Boediono. 1982. Teori Pertumbuhan Ekonomi. Sinopsis Pengantar Ilmu Ekonomi Pertanian No.4. BPFE, Yogyakarta.

BPS. 2013. Banda Aceh.

Dinas Pertanian Tanaman Pangan. 2014. Banda Aceh.

Departemen Pertanian. 1980. Vadimicum Pertanian. 